16 Cox DR. Regression models and life-tables. Fournal of the Royal Statistics Society, Series $B$ 1972;34:187-220.
(1)

1 Barker VF. Periphe 1975:220-53

A. Effect of daily muscular exercise in patients with intermitent Larsen OA, Lassen NA. Effect of
claudication. Lancet 1966;i:1093-5.

3 Ericsson B, Haeger $\mathrm{K}$, Lindell SE. Effect of physical training on intermittent claudication. Angiology 1979;21:188-92.

4 Quick CRG, Cotton LT. The measured effect of stopping smoking on intermittent claudication. Brf Surg 1982;69(suppl):S24-6.

5 Hughson WG, Mann JI, Tibbs DJ, Woods HF, Walton I. Intermittent claudication: factors determining outcome. BrMed $\mathcal{F} 1978 ;$ i: $1377-9$.

6 Mathiesen FR, Errebo Larsen E, Wulff M. Some factors influencing the spontaneous course of arterial insufficiency. Acta Chir Scand 1970;136:303-8.

7 Juergens JL, Barker NW, Hines EA. Arteriosclerosis obliterans: review of 520 cases with special reference to pathogenic and prognostic factors. Circulation 1960;21:188-95.

8 Imparato AM, Kim G-E, Davidson T, Crowley JG. Intermittent claudication: its natural course. Surgeny 1975;78:795-9.

9 McAllister FF. The fate of patients with intermittent claudication managed nonoperatively.

10 Bloor K. Natural history of arteriosclerosis of the lower extremities. Ann R Coll Surg Engl $1961 ; 28: 36-52$

11 Tonnesen KH, Noer I, Paaske W, Sager Ph. Classification of peripheral occlusive diseases based on symptoms, signs and distal blood pressure measurements. Acta Chir Scand 1980;146:101-4. 12 Strandness DE, Bell JW. Peripheral vascular disease: diagnosis and objective evaluation using a mercury strain gauge. Ann Surg 1965;161:3-32.

13 Holstein P, Lassen NA. Healing of ulcers on the feet correlated with distal blood pressure measurements in occlusive arterial disease. Acta Orthop Scand 1980;51:995-1006.

14 Ramsey DE, Manke DA, Sumner DS. Toe blood pressure. A valuable adjunct to ankle pressure measurement for assessing peripheral arterial disease. $\mathcal{f}$ Cardiovasc Surg 1983;24:43-8.

15 Peto R, Pibe MC, Armitage P, et al. Design and analysis of randomized clinical trials requiring prolonged observation of each patient. II. Analysis and examples. Br f Cancer 1977;35:1-39.
Horwitz N, Dalgaard OZ. Dodelighedsforskelle som indikator for uensartet sundhedstilstand fra amt til amt. Ugeskr Laeger 1985;147:2105-13.

18 Bogaert MG Clement DL. Lack of influence of propranolol and metoprolol on walking distance in $\widehat{\Omega}$ patients with chronic intermittent claudication. Eur Heart 7 1983;4:203-4 chronic antihypertensive treatment with metoprolol and methyldopa. Clin Physiol 1984;4: ग] $275-82$

20 Svendsen TL, Jeines R. Tonnesen $\mathrm{KH}$. The effects of acebutolol and metoprolol on walking $\Pi$ distances and distal blood pressure in hypertensive patients with intermittent claudication. Acta $\varrho$ Med Scand 1986;219:161-5.

21 Jarrett RJ, Keen H, Chakrabarti R. Diabetes, hyperglycaemia and arterial disease. In: Keen $\mathrm{H}, \overrightarrow{\overline{\vec{F}}}$ Jarrett RJ, eds. Complications of diabetes. 2nd ed. London: Edward Arnold Ltd, 1982:180-2.

22 Jonason T, Ringqvist I. Diabetes mellitus and intermittent claudication. Actu Med Scand 1985;218:217-21

23 Reunanen A, Takkunen H, Aromaa A. Prevalence of intermittent claudication and its effect on mortality. Acta Med Scand 1982;211:249-56.

24 Kannel WB, Shurtieff $D$. Cigarettes and the development of intermittent claudication-the $\underset{\mathbb{D}}{\vec{D}}$ Framingham study. Geriatrics 1973;28:61-8. 25 Hughson WG, Mann JI, Garrod A. Intermittent claudication: prevalence and risk factors.

26 US Department of Health and Human Services. The health consequences of smoking. A report of the $\vec{O}$ Surgeon General. Bethesda, Md: National Institutes of Health, 1983:182-6.

27 Clifford PC, Davies PW, Hayne JA, Baird RN. Intermittent claudication: is a supervised exercise $\vec{A}$ class worth while? BrMed f 1980;280: 1503-5.

28 Rosetzsky A, Struckmann J, Mathiesen FR. Minimal walking distance following exercise oิ treatment in patients with arterial occlusive disease. Ann Chir Gynaecol 1984;74:261-4.

(Accepted 5 August 1986)

\title{
Assessment of non-mydriatic fundus photography in detection of diabetic retinopathy
}

\author{
ROBERT WILLIAMS, STEPHEN NUSSEY, ROGER HUMPHRY, GRAHAM THOMPSON
}

\begin{abstract}
Non-mydriatic retinal photography with later interpretation of the photographs was assessed as a screening method for the detection of diabetic retinopathy; when compared with an ophthalmologist's clinical assessment in a random group of 62 diabetic patients it was accurate (false negative $6.8 \%$, false positive $2 \%$ ) and sensitive (sensitivity $96 \%$, specificity $98 \%$ ). The assessment of further management required based on analysis of the photographs was $96.5 \%$ in agreement with the further management suggested by the ophthalmologist after direct clinical assessment of the patient.
\end{abstract}

If this technique were used to screen patients in a typical diabetic clinic the predicted positive accuracy rate would be $84 \%$ and the predicted negative accuracy rate $99.5 \%$.

\section{Introduction}

Diabetic eye disease is the commonest cause of blindness in people of working age ${ }^{12}$ despite the widespread availability of effective photocoagulation treatment. ${ }^{34}$ Many diabetics are not regularly screened for treatable eye disease and present with advanced

St George's Hospital, London SW17

ROBERT WILLIAMS, MRCP, FRCS, senior registrar, ophthalmic unit STEPHEN NUSSEY, MRCP, Wellcome lecturer, diabetic unit

ROGER HUMPHRY, FRCS, registrar, ophthalmic unit

GRAHAM THOMPSON, FRCS, consultant ophthalmologist, ophthalmic unit

Correspondence to: Mr Williams, Worthing Hospital, Worthing, West Sussex BN11 2DH disease, for which treatment is difficult, expensive, and lessड effective. Screening has been shown to be cost effective, ${ }^{5}$ but thereo are insufficient ophthalmologists to screen all diabetics. ' Currently, screening is mainly by fundal examination performed by medical $\mathbb{Q}$ staff, which is expensive and has been shown to be inaccurate. $\overrightarrow{0}$ There is an urgent need for a cheaper screening method that does 3 not need to be performed by specialists in ophthalmology.

Non-mydriatic retinal photography, a recently developed tech nique, has been reported as a method of recording the fundas appearance. ${ }^{9}$ Although it has been compared with standard $30^{\circ}$ stereophotography and direct ophthalmoscopy by a technician: through an undilated pupil,,$^{10}$ it has not been compared with an ophthalmologist's assessment. We assessed non-mydriatic retinah photography as a means of detecting diabetic retinopathy and compared the results with those obtained by direct examination by an ophthalmologist and a doctor with an interest in diabetes.

\section{Patients and methods}

The protocol was approved by the ethical committee. Patients werf selected at random from those attending a general diabetic clinic and a diabetic eye disease clinic. After giving informed consent they were assesseck in three ways. Firstly, the patients' fundi were examined by the doctor (thi\& was his usual screening practice in the diabetic clinic), and their pupils were dilated. Secondly, single retinal photographs were taken of each eye through ${ }^{+}$ the undilated pupil using either the Kowa or the Canon CR3 non-mydriatic fundus cameras with either Polaroid 600 colour prints film or Kodachrome ASA 200 colour transparency film. Both cameras photograph around $45^{\circ}$ of the fundus, and they were positioned so that the area photographed exten $\mathbb{\Omega}$ ded from just nasal to the optic disc to temporal to the macula. The photographs were assessed by two ophthalmologists after all the patients had been studied. Finally, the patients' fundi were examined through dilated pupilo by an ophthalmologist, using both direct and indirect ophthalmoscopy.

Both examinations and the photographic interpretation were undertaket. 
without knowledge of the other assessors' findings or of the diabetic or ophthalmic history. All findings were recorded on a form that included a fundal diagram and a description of the findings. All patients were undergoing routine follow up in either the general diabetic or the diabetic eye clinic, and the assessors recorded whether they considered this to be sufficient or specialist investigation or treatment to be required. On photographic interpretation the quality of definition of retinal detail was graded subjectively on a five point scale: $1=$ excellent, $2=$ definition of most retinal detail, $3=$ definition limited but most detail visible, $4=$ only gross detail visible, and $5=$ no detail visible. positive rate of $4 \%$. He detected maculopathy with a sensitivity of $94 \%$ and a specificity of $95 \%$ and neovascularisation with a sensitivity of $78 \%$ and a specificity of $95 \%$. In two cases the doctor considered neovascularisation to be present, but the ophthalmologist considered these to be cilioretinal vessels, a normal variant.

Table II shows the clinical management advised by the ophthalmologist after photographic interpretation compared with that thought necessary by the ophthalmologist after direct examination of the patients. Photographic interpretation was seen to agree with examination in $94 \%$ of cases, to be over zealous in $2.5 \%$, and not to prompt sufficient action in $3.5 \%$. Therefore, in

TABLE I-Ophthalmologist's diagnosis after clinical examination of patients compared with diagnoses after inspection of photographs and doctor's examination

\begin{tabular}{|c|c|c|c|c|c|c|c|c|}
\hline \multirow[b]{2}{*}{ Ophthalmologist's assessment } & \multicolumn{4}{|c|}{ Photographic assessment } & \multicolumn{4}{|c|}{ Doctor's assessment } \\
\hline & $\begin{array}{l}\text { Nothing } \\
\text { abnormal } \\
\text { detected }\end{array}$ & $\begin{array}{l}\text { Background } \\
\text { retinopathy }\end{array}$ & Maculopathy & $\begin{array}{c}\text { New } \\
\text { vessels }\end{array}$ & $\begin{array}{l}\text { Nothing } \\
\text { abnormal } \\
\text { detected }\end{array}$ & $\begin{array}{l}\text { Background } \\
\text { retinopathy }\end{array}$ & Maculopathy & $\begin{array}{c}\text { New } \\
\text { vessels }\end{array}$ \\
\hline Nothing abnormal detected & 41 & 1 & 0 & 0 & 39 & 3 & 0 & 0 \\
\hline Background retinopathy & 3 & 22 & 3 & 0 & 4 & 18 & 4 & 2 \\
\hline Maculopathy & 0 & 0 & 32 & 0 & 0 & 2 & 30 & 0 \\
\hline New vessels & 0 & 0 & 2 & 9 & 1 & 2 & 0 & 8 \\
\hline
\end{tabular}

TABLE II-Management recommended after inspection of photograph compared with that recommended by opthalmologist after clinical examination

\begin{tabular}{lrrc}
\hline & \multicolumn{3}{c}{ Ophthalmologist's assessment } \\
\cline { 2 - 4 } Photographic assessment & Follow up & Investigation & Treatment \\
\hline Follow up & 64 & 3 & 0 \\
Investigate & 3 & 10 & 0 \\
Treatment & 0 & 1 & 32 \\
\hline
\end{tabular}

Statistical calculation of sensitivity, specificity, false negative rate, false positive rate, and predictive accuracy was performed as recommended by Feinstein. ${ }^{.1}$ The predictive accuracy of the technique when used in a typical general diabetic clinic was calculated by assuming a $10 \%$ prevalence of diabetic retinopathy in the clinic as reported. ${ }^{12}$

\section{Results}

One hundred and twenty eyes of 62 patients were studied, 86 with Polaroid film and 34 with transparencies. Photographic quality was classed as grade 1 in 56 eyes $(47 \%)$, as grade 2 in $27(23 \%)$, as grade 3 in eight $(7 \%)$, and as grade 5 in seven $(6 \%)$. Proliferative retinopathy, confirmed by the ophthalmologist, was noted in Polaroid prints of grades 1-3 and in transparencies of grades 1-2 (it had not been noted by the ophthalmologist in eyes of which the photographs were of poorer quality). Maculopathy was noted in Polaroid prints and transparencies of grades 1-4.

Of 113 eyes with photographs of grade 4 or higher, $73(60 \%)$ were though to show diabetic retinopathy by the ophthalmologist, $69(58 \%)$ by the doctor, and $69(58 \%)$ on photographic interpretation (table I). The ophthalmologist considered retinopathy to be present in 71 eyes, and this was detected by the camera with a sensitivity of $96 \%$, a specificity of $98 \%$, a false negative rate of $6 \cdot 8 \%$, and false positive rate of $2 \%$.

Maculopathy was considered to be present in 32 eyes and was detected from the photographs with a sensitivity of $100 \%$ and a specificity of $96 \%$. Neovascularisation was considered to be present in 11 eyes, nine with new vessels on the disc and two with new vessels elsewhere, and was detected from the photographs with a sensitivity of $82 \%$ and a specificity of $100 \%$.

Using the determined sensitivity and specificity and the reported prevalence of retinopathy in a general diabetic clinic of $10 \%$, we calculated the predictive value of this method. If used in a general diabetic clinic screening by non-mydriatic retinal photography would give a positive accuracy of $84 \%$ and a negative accuracy of $99.5 \%$ - that is, if retinopathy is thought present in the photograph it is $84 \%$ likely to be correct and if retinopathy is not detected it is $99 \cdot 5 \%$ likely to be correct.

Table I shows the comparison between the doctor's direct clinical assessment and the ophthalmologist's direct clinical assessment. From this i may be calculated that the doctor detected overall retinopathy with a sensitivity and specificity of $93 \%$, a false negative rate of $11 \%$, and a false

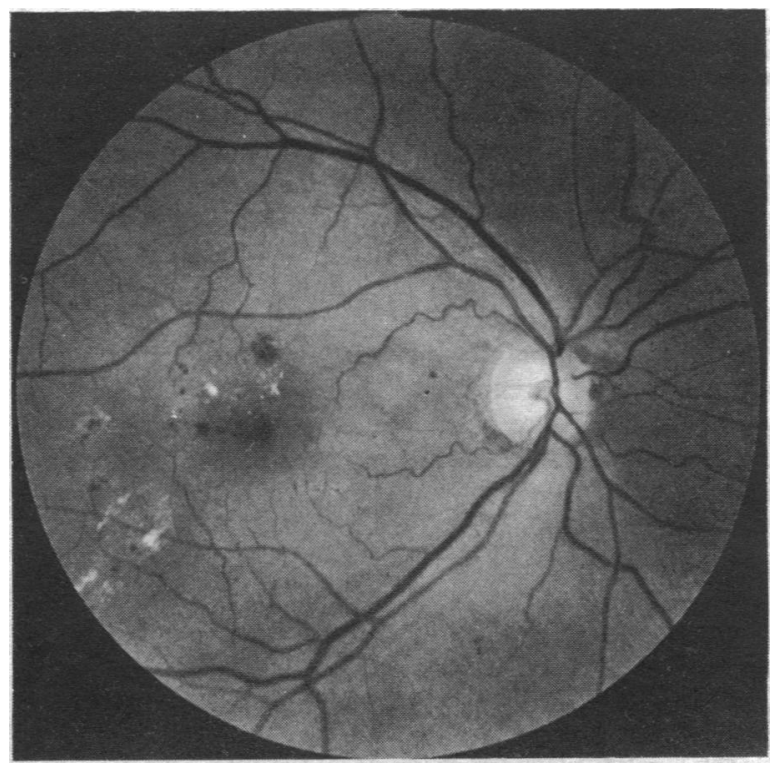

Non-mydriatic $45^{\circ}$ retinal photograph showing circinate maculopathy that requires treatment. The ophthalmoscopic detection of this would usually require mydriasis.

$96.5 \%$ of cases with adequate photographs safe clinical management was determined by photographic analysis alone. In only $6 \%$ of eyes was it thought necessary to repeat the photograph.

\section{Discussion}

The prevalence of retinopathy in a general diabetic clinic is about $10 \% .^{72}$ The percentage was much higher in our series because of the deliberate inclusion of patients referred to a diabetic eye disease clinic so that the detection of serious diabetic eye disease by nonmydriatic photography might be evaluated.

The wide angle high quality photographs that we used (figure) allowed rapid examination of the posterior pole of the eye. The overall false negative rate of $6.8 \%$ and false positive rate of $2 \%$ (compared with the ophthalmologist's assessment) indicate that the technique of non-mydriatic retinal photography is a good screening method for diabetic retinopathy. The high sensitivity shows that this technique would detect most retinopathy and the high specificity shows that this would not be at the expense of excessive 
recall of normal patients. The clinical decision-that is, the action recommended when reporting on the photograph-even though some detail may not have been recorded, agreed with direct assessment by the ophthalmologist in $96.5 \%$ of cases. Studies using fundus photography (mydriasis and seven stereophotographs for each eye) have shown this to be more accurate than ophthalmologists in detecting diabetic retinopathy..$^{13}$ Thus the false negative rate may have been higher, but as seven field mydriatic fundus photography is not suitable for screening the ophthalmologist was used for comparison.

An important aspect of screening for diabetic retinopathy is the sensitivity to proliferative retinopathy. The determined sensitivity of non-mydriatic fundus photography is better than that reported for diabetologists. ${ }^{8}$ In addition, of the 11 cases of proliferative retinopathy identified by the ophthalmologist, two were overlooked by the observers reporting on the photographic appearance because they were distracted by a coexisting maculopathy. When these photographs were re-examined at the end of the study the neovascularisaton was clearly seen; thus this was an error of reporting and not of photographic recording.

This study did not show any definite advantage of either Polaroid or transparencies for recording. We believe, however, that transparencies record more detail. In addition, the ease of projection with magnification for reporting, lower cost, and ease of storage increase our preference for the use of transparencies.

The cost effectiveness of screening for diabetic retinopathy has already clearly been shown. ${ }^{5}$ Non-mydriatic photography provides an effective screening method that is cheap and easy to use. Mass screening for diabetic eye disease is not at present widely available. Future changes in medical education may, hopefully, improve the screening by non-specialist medical staff. The doctor in this study has an interest in diabetes, routinely uses mydriasis, and has previously attended diabetic eye clinics. His excellent rate of detection was far higher than that reported for general doctors. ${ }^{8}$ Screening using ophthalmic opticians has been suggested,,${ }^{14}$ but this has been criticised as expensive and their accuracy has not been assessed fully. ${ }^{15} 16$ There are insufficient ophthalmologists to screen all diabetics, but indirect screening using photographs may be feasible.
We consider non-mydriatic retinal photography to be an effective $\underline{\underline{T}}$ method of screening for diabetic eye disease. The provision of a 3 photographic service in a general diabetic clinic, or in the com- $\underset{\mathbb{Q}}{\Omega}$ munity, with later interpretation of the photographs (preferably by $c$ the ophthalmologist who would be called on to administer treat- $\widehat{\widehat{O}}$ ment) is an accurate and cost effective method of screening for $\overline{\bar{J}}$ diabetic retinopathy. Further studies are required to confirm this.

We thank Professor T R E Pilkington and Mr I Luke for their help and permission to include their patients in the study.

\section{References}

1 Department of Health and Social Security. Blindness and partial sight in England 1969-1976. London: HMSO, 1979. (Reports in Public Health Subjects, No 129.)

2 Ghaffour IM, Allan D, Foulds WS. Common causes of blindness and visual handicap in the west of Scotland. Brf Ophthalmol 1983;67:209-13.

3 The diabetic retinopathy study group. Photocoagulation of proliferative diabetic retinopathy. $\vec{\circ}$ Ophthalmology (Rochester) 1981;88:583-600.

4 British multicentre study group. Photocoagulation for diabetic maculopathy: a randomised $\vec{\omega}$ clinical trial using the xenon arc. Diabetes 1984;32:1010-6.

5 Foulds WS, McCuish AM, Barrie T, et al. Diabetic retinopathy in the west of Scotland: its detection and prevalence, and the cost-effectiveness of a proposed screening programme. Health Bull (Edin) 1983;41:318-26.

6 Blach RK, Bloom A. Diabetic eye centres for the management of diabetic eye disease. Health Trends 1978;10:82-90.

7 Scobie IN, MacCuish AC, Barrie T, Green FD, Foulds WS. Serious retinopathy in a diabetic clinic: prevalence and therapeutic implications. Lancet $1981 ;$ ii: $520-1$.

8 Sussman ES, Tsiaras WG, Soper KA. Diagnosis of diabetic eye disease. JAMA 1982;247:3231-4. of

9 Ryder REJ, Vora JP, Atiea JA, Owens DR, Hayes TM, Young S. Clinical topics: possible new method to improve detection of diabetic retinopathy. $\mathrm{Br} \mathrm{Med} \mathcal{F}$ 1985;291:1256-7.

10 Klein R, Klein BEK, Neider MW, Hubbard LD, Meuer SM, Brothers RJ. Diabetic retinopathy as detected using ophthalmoscopy, a non-mydriatic camera and a standard fundus camera. Ophthalmology (Rochester) 1985;92:485-91.

11 Feinstien AR. On the sensitivity, specificity and discrimination of diagnostic tests. In: Feinstien AR, ed. Clinical biostatistics. St Louis: Mosby, 1977.

12 Donovan RJ. Prevalence of retinopathy in a diabetic clinic. Br Med f 1978;286:1441-2.

13 Moss SE, Klein R, Kessler SD, Richie KA. Comparison between ophthalmoscopy and fundus $O$ photography in determining severity of diabetic retinopathy. Ophthalmology (Rochester) photography

14 Burns-Cox CJ, Hart JCD. Screening of diabetics for retinopathy by ophthalmic opticians. BrMed f 1985;290:1052-4.

15 Bhopal RJ, Hedley AJ. Screening of diabetics for retinopathy by ophthalmic opticians. $\operatorname{Br} \operatorname{Med} \mathcal{f} \vec{\oplus}$ 1985;290:1589.

16 Williams R. Screening for diabetic retinopathy. Br Med f 1985;290:1349-50.

(Accepted 15 August 1986)

\section{SHORT REPORTS}

\section{Acute renal failure after overdose of labetalol}

Renal failure after overdose of $\beta$ blockers or labetalol has not been reported, despite usually severe and prolonged hypotension. We describe a patient who developed acute oliguric renal failure after a massive overdose of labetalol.

\section{Case report}

A 19 year old previously healthy woman was admitted one hour after attempting to commit suicide by ingesting $16 \mathrm{~g}$ labetalol. She did not take any drugs regularly, and her blood pressure was usually $120 / 60 \mathrm{~mm} \mathrm{Hg}$. On admission she was alert with a blood pressure of $80 / 60 \mathrm{~mm} \mathrm{Hg}$ and pulse of 76 beats/min. Further physical examination yielded unremarkable results. Despite infusion of $250 \mathrm{ml}$ plasma her blood pressure fell to $70 / 50 \mathrm{~mm} \mathrm{Hg} 20$ minutes after her admission but 10 minutes later rose to $85 / 60 \mathrm{~mm} \mathrm{Hg}$ after infusion of another $250 \mathrm{ml}$ plasma. Gastric lavage was performed and activated charcoal administered. Another $500 \mathrm{ml}$ plasma and dopamine $2 \mu \mathrm{g} / \mathrm{kg} / \mathrm{min}$ were given to maintain systolic blood pressure above $100 \mathrm{~mm} \mathrm{Hg}$. No rhythm or conduction disturbances occurred apart from transient first degree atrioventricular block. The serum labetalol concentration was $2850 \mu \mathrm{g} / \mathrm{l}$ on admission (concentrations above 500 $\mu \mathrm{g} / \mathrm{l}$ are toxic) and fell to $60 \mu \mathrm{g} / \mathrm{l}$ the next day. Toxicological screening indicated that she had not taken any other drugs.

Urine output was $25 \mathrm{ml}$ in the first hours after admission and failed to increase despite continued infusion of dopamine $2 \mu \mathrm{g} / \mathrm{kg} / \mathrm{min}$ and the administration of frusemide $40 \mathrm{mg}$ five hours after admission. While blood pressure was $130 / 70 \mathrm{~mm}$
Hg a Swan-Ganz catheter was inserted; central venous pressure of $6 \mathrm{~mm} \mathrm{Hg}$, cardiac output of $91 / \mathrm{min}$, and systemic vascular resistance of $74.5 \mathrm{kPa} . \mathrm{s} / 1\left(745 \sum\right.$ dyn.s $/ \mathrm{cm}^{5}$ ) were recorded. Oliguria persisted, with a maximum urine output of $\bar{O}$ $420 \mathrm{ml}$ on the fifth day after ingestion. Serum urea concentration rose from $3 \cdot 43$. $\mathrm{mmol} / \mathrm{l}(20 \mathrm{mg} / 100 \mathrm{ml})$ on admission to $28.0 \mathrm{mmol} / \mathrm{l}(168 \mathrm{mg} / 100 \mathrm{ml})$ five days later, and serum creatinine concentration rose from $113 \mu \mathrm{mol} / 1(1.3 \mathrm{mg} / 100 \mathrm{ml})$ to $1144 \mu \mathrm{mol} / 1(12.9 \mathrm{mg} / 100 \mathrm{ml})$. Urinary sodium concentration was 10 $\mathrm{mmol}(\mathrm{mEq}) / \mathrm{l}$ and urea concentration $4 \mathrm{mmol} / 1(24 \mathrm{mg} / 100 \mathrm{ml})$ in a urine sample $\frac{0}{7}$ obtained the morning after admission. No rash or eosinophilia developed, and no $\mathrm{N}$ myoglobinuria was found. A renal biopsy three days after ingestion showed mild $\mathcal{O}$ local tubular necrosis and no abnormalities in glomeruli or interstitium. I Haemodialysis was performed on the sixth hospital day and repeated twice afterwards.

On the 10th day urine output increased again and renal function recovered $\mathrm{N}$ rapidly: serum urea concentration fell to $6.4 \mathrm{mmol} / \mathrm{l}(38 \mathrm{mg} / 100 \mathrm{ml})$ on the $23 \mathrm{rd} \mathrm{N}$ day, when she was discharged, and was $3.8 \mathrm{mmol} / \mathrm{l}(23 \mathrm{mg} / 100 \mathrm{ml})$ four months $\sigma$ later; serum creatinine concentration was 113 and $74 \mu \mathrm{mol} / 1(1.3$ and $0.8 \mathrm{mg} / 100<$ $\mathrm{ml})$, respectively. Renal function studies showed a glomerular filtration rate of 190 $\mathrm{ml} / \mathrm{min} 15$ days after ingestion and $102 \mathrm{ml} / \mathrm{min}$ four months later, effective renal

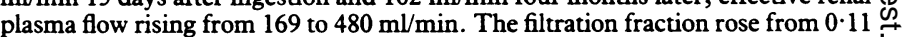
to $0 \cdot 21$.

\section{Comment}

It is remarkable that despite usually severe and prolonged hypotension $\bar{\sigma}$ acute renal failure after an overdose of a $\beta$ blocker has not been reported. ${ }^{1}$ In our patient acute oliguric renal failure developed after a short period of 0 moderate hypotension. Causes such as myoglobinuria and interstitialnephritis were excluded. The tubular necrosis and initially low filtrationo 